\title{
Redefinisi Kosakata Terkait Perang Bahasa (Kajian Linguistik Forensik)
}

\author{
Vocabulary Redefinition Related to Language Wars (Forensic Linguistics Studies)
}

\author{
Ali Kusno \\ Kantor Bahasa Provinsi Kalimantan Timur \\ Corresponding email: ali.kusno@kemdikbud.go.id
}

Received: 28 January 2021 Accepted: 29 May 2021 Published: 1 August 2021

\begin{abstract}
The purpose of this study is to formulate a redefinition of vocabulary related to language wars. This study uses descriptive qualitative research methods. The data analysis technique uses an interactive model consisting of three analysis components: data reduction, data presentation, and drawing conclusions or verification. The activities of the three components are carried out in an interactive form with the data collection process. The rise of legal cases related to language is in line with the increasingly massive use of social media in society. These cases are part of the language war. Society, in general, is still common and even misunderstands related speech that is categorized as language war and has the potential to be caught in the law. Language war is the use of the language of a speaker/writer intentionally as a tool/weapon for self or group interests. Language wars are carried out directly or indirectly that attack the ideas, thoughts, behaviour, honour, or physical condition of a person or group of speech partners. Language wars include suggestions, criticism, ridicule, incitement, defamation, insults, and slander. More detailed definitions and socialization efforts to the public regarding various language criteria are preventive measures for various legal cases related to language.
\end{abstract}

Keywords: redefinition of language war vocabulary, legal bondage, forensic linguistics

\begin{abstract}
Abstrak: Tujuan penelitian ini untuk merumuskan definisi ulang kosakata terkait perang bahasa. Penelitian ini menggunakan metode penelitian kualitatif deskriptif. Teknik analisa data menggunakan model interaktif, yang terdiri atas tiga komponen analisis, yaitu reduksi data, sajian data, dan penarikan simpulan atau verifikasi. Aktivitas ketiga komponen itu dilakukan dalam bentuk interaktif dengan proses pengumpulan data. Maraknya kasus hukum terkait kebahasaan selaras dengan semakin masifnya penggunaan media sosial di masyarakat. Berbagai kasus tersebut merupakan bagian dari perang bahasa. Masyarakat secara umum masih awam bahkan salah pemahaman terkait tuturan yang berkategori perang bahasa dan berpotensi jeratan hukum. Perang bahasa merupakan penggunaan bahasa seorang penutur/penulis yang dilakukan secara sengaja sebagai alat/senjata untuk kepentingan diri sendiri ataupun kelompok. Perang bahasa dilakukan secara langsung maupun tidak langsung yang menyerang gagasan, pikiran, perilaku, kehormatan, atau kondisi fisik seseorang atau sekelompok mitra tutur. Perang bahasa meliputi saran, kritik, ejekan, hasutan, pencemaran nama baik, penghinaan, dan fitnah. Definisi secara lebih rinci dan upaya sosialisasi kepada masyarakat tentang beragam kriteria bahasa merupakan upaya preventif berbagai kasus hukum terkait kebahasaan.
\end{abstract}

Kata kunci: redefinisi kosakata perang bahasa, jeratan hukum, linguistik forensik

\section{To cite this article:}

Kusno, A. (2021). Redefinisi Kosakata Terkait Perang Bahasa (Kajian Linguistik Forensik). Diglosia: Jurnal Kajian Bahasa, Sastra, dan Pengajarannya, 4(3), 287-300. https://doi.org/10.30872/diglosia.v4i3.183 


\section{A. PENDAHULUAN}

Pesatnya perkembangan teknologi telah memudahkan masyarakat untuk berinteraksi dan mengakses informasi. Keberadaan dan kemajuan pembaruan media sosial juga telah membuat jarak antarpersona begitu dekat dan serba cepat. Selain itu, pembaruan tersebut memungkinkan masyarakat biasa bisa langsung berinteraksi dengan pihak-pihak yang dianggap susah dijangkau, seperti kalangan artis dan pejabat publik.

Kemudahan dan kecepatan itu berdampak negatif menimbulkan euforia publik yang berlebihan. Publik merasa bebas tanpa batas menyampaikan opini, sanggahan, dan kritikan. Tipisnya batasan kebahasaan antara opini, sanggahan, kritikan, hinaan, membuat sebagian pengguna media sosial tergelincir dalam kasuskasus hukum, seperti penghinaan dan pencemaran nama baik. Sebagian besar kasus pelanggaran UU ITE selama ini terjadi karena unggahan-unggahan dan komentar di media sosial, seperti Facebook, Twitter, Youtube, TikTok dan aplikasi lainnya.

Persentase kasus pelanggaran UU ITE di media sosial cukup variatif tergantung jenis media sosial. Urutan pertama ditempati pengguna Facebook dengan jumlah sebesar 54,69 persen. Selanjutnya, pengguna Twitter yang mencapai 11,84 persen dan Youtube sebesar 4,90 persen. Laporan kasus sering memuat alat bukti lebih dari satu platform karena terkadang muatan yang sama diunggah di platform berbeda. Selain dari platform media sosial, sarana lain yang pernah terekam dalam pelaporan kasus UU ITE adalah platform komunikasi pesan (messenger). Media tersebut umumnya tidak bersifat publik, seperti $S M S$ (pesan singkat) (3,27 persen), Whatsapp (2,45 persen), dan $B B M$ (0,82 persen) (Gerintya, 2020). Hanya saja, ada tren kenaikan kasus penggunaan pesan whatsapp karena memungkinkan adanya grup whatsapp dan status whatsapp. Konflik antaranggota grup whatsapp sering terjadi.

Maraknya kasus UU ITE pada sisi lain membuat pemerintah bertindak tegas membuat batasan-batasan dalam bermedia sosial. Namun hal itu dimaknai sebagai sebuah kemunduran oleh sebagian masyarakat karena dianggap membungkam kebebasan berpendapat. Berdasarkan paparan Komjen Pol. Drs. Listyo Sigit Prabowo, M.Si. pada Uji Kelayakan dan Kepatutan Calon Kapolri di Hadapan Komisi III DPR RI Tahun 2021, dalam penegakkan hukum pada tindak pidana siber, sepanjang tahun 2020 terdapan 6 kasus terbanyak dari 15 kategori kasus kejahatan menonjol, meliputi pencemaran nama baik, penipuan, pornografi, akses ilegal, ujaran kebencian/SARA, dan hoaks. Total penyelesaian perkara sebanyak 1.462 kasus dari 4.800 kasus pada tahun 2020 (30\% penyelesaian perkara) (Prabowo, 2021, p. 61).

Salah satu upaya untuk mengantisipasi maraknya kasus ujaran kebencian, Kapolri mengeluarkan Surat Edaran Nomor: SE/2/11/2021 tentang Kesadaran Budaya Beretika untuk Mewujudkan Ruang Digital Indonesia yang Bersih, Sehat, dan Produktif. Dalam surat edaran itu salah satunya memuat petunjuk bahwa dalam menerima laporan dari masyarakat, penyidik harus dapat dengan tegas membedakan antara kritik, masukan, hoaks, dan pencemaran nama baik yang dapat dipidana untuk selanjutnya menentukan langkah yang akan diambil. Oleh karena itu, penyidik dalam menerima laporan masyarakat harus memahami perbedaan antara kritik, masukan, hoaks, dan pencemaran nama baik. Hal ini menjadi permasalahan tersendiri bagi kalangan penyidik. 


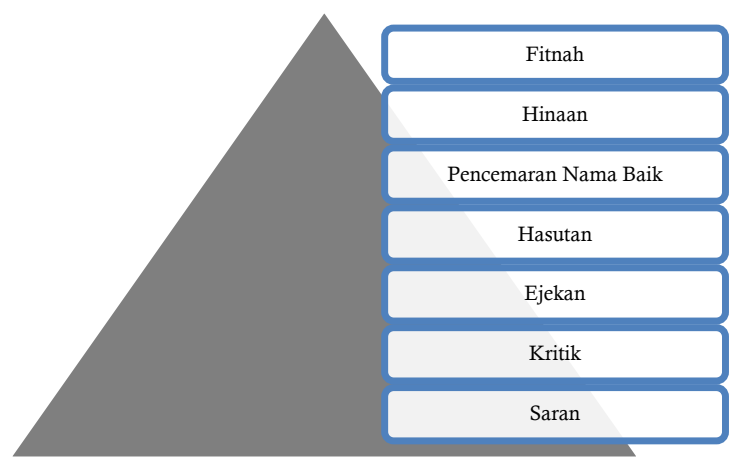

Gambar 1. Derajat Perang Bahasa (Aziz, 2020)

Pada sisi lain, masyarakat umum pun juga kesulitan membedakan antara kritik, masukan, hoaks, dan pencemaran nama baik. Hal itu pulalah yang menyebabkan banyaknya kasus hukum yang melibatkan alat bukti bahasa. Maraknya kasus ujaran kebencian disebabkan batasan yang tidak jelas antara kritikan, saran, pencemaran nama baik dan lainnya. Dalam konteks linguistik forensik, kasus-kasus hukum terkait kebahasaan dinamakan perang bahasa. Kepala Badan dan Pengembangan Bahasa, E. Aminuddin Aziz, mengungkapkan bahwa perang bahasa merupakan penggunaan bahasa seorang penutur/penulis yang dilakukan secara sengaja sebagai alat/senjata untuk kepentingan diri sendiri ataupun kelompok. Perang bahasa dilakukan secara langsung maupun tidak langsung yang menyerang gagasan, pikiran, perilaku, kehormatan, atau kondisi fisik seseorang atau sekelompok mitra tutur (Aziz, 2020). Derajat perang bahasa tersebut meliputi saran, kritik, ejekan, hasutan, pencemaran nama baik, hinaan, dan fitnah. Ilustrasi derajat perang bahasa dari paling rendah sampai yang paling tinggi dapat dilihat pada Gambar 1 di atas.

Pengguna media sosial terlibat perang bahasa karena menyerang gagasan, pikiran, perilaku, kehormatan, atau kondisi fisik seseorang atau sekelompok mitra tutur, baik dilakukan secara langsung maupun tidak langsung, melalui media sosial. Kasus-kasus hukum terkait perang bahasa sebenarnya dalam konteks linguistik forensik diduga disebabkan ketidaktahuan publik terhadap batasan-batasan perang bahasa: kritikan dengan penghinaan, pencemaran nama baik dan sebagainya. Selain itu, berbagai persoalan hukum yang menjerat sebagian masyarakat tersebut, salah satunya didahului masih tipisnya batasan-batasan antara saran, kritik, ejekan, hasutan, pencemaran nama baik, hinaan, dan fitnah. Pemaknaan kosakatakosakata yang terkait dengan hukum perlu dipertegas agar niat masyarakat yang awalnya ingin mengkritik tidak tergelincir dalam penghinaan, fitnah, maupun pencemaran nama baik.

Masyarakat memaknai kata-kata terkait perang bahasa tersebut seperti yang sudah berkembang di masyarakat. Selain itu, dasar pemaknaan kosakata bagi masyarakat berdasarkan definisi yang terdapat di dalam Kamus Bebas Bahasa Indonesia (KBBI). Apabila dicermati di dalam KBBI, definisi kosakata-kosakata tersebut masih terlalu sempit sehingga menjadi celah bagi ketidaktahuan masyarakat. Sebaliknya, pemaknaan di dalam peraturan perundang-undangan justru lebih luas jabarannya, sedangkan masyarakat pun sebagian besar tidak mengerti dunia hukum. Dengan demikian, perlu ada kajian untuk 
memformulasikan definisi ulang (redefinisi) kosakata perang bahasa dengan menggunakan berbagai sumber rujukan.

Oleh karena itu, penelitian ini bertujuan untuk meredefinisi pemaknaan kosakata-kosakata yang terkait dengan kasus kebahasaan dengan mempertegas batas pengertian dan pemahaman perang bahasa. Dalam KBBI V ("Definisi," 2021) pengertian 'definisi' adalah rumusan tentang ruang lingkup dan ciri-ciri suatu konsep yang menjadi pokok pembicaraan atau studi. Dengan demikian, dapat dipahami bahwa redefinisi merupakan membuat ulang rumusan tentang ruang lingkup dan ciri-ciri suatu konsep yang menjadi pokok pembicaraan atau studi. Hasil penelitian ini bermanfaat bagi masyarakat dalam membedakan pemaknaan kosakata terkait perang bahasa, penyidik dalam menganalisis kasus, ahli bahasa dalam menganalisis alat bukti hukum bahasa, dan manfaat lainnya bagi pihak terkait.

Dalam membuat redefinisi tentang perang bahasa memperhatikan pemaknaan $K B B I V$, peraturan perundang-undangan, dan konteks kasus-kasus hukum ujaran kebencian. Selain itu, juga mempertimbangkan pemaknaan secara kontekstual dengan memperhatikan teori-teori tindak tutur untuk mengetahui derajat dampak sebuah tuturan. Analisis tuturan dilakukan terhadap semua unsur tuturan, memperhatikan penunjang pemaknaan gejala berbahasa (paralinguistic concomitants), dan konteks kejadian berbahasa sebagai unsur kunci (Aziz, 2020).

Saifudin (2020, pp. 1-16) mengungkapkan ulasan teori tindak tutur sebagai berikut. Teori tindak tutur dikategorikan Austin tuturan menjadi dua jenis, yakni tuturan konstatif dan tuturan performatif. Berdasarkan pandangan Austin, tuturan konstatif timbul dengan mengatakan sesuatu yang memiliki dampak sebuah properti menjadi benar atau salah (Austin, 1962). Tuturan konstatif meliputi semua ucapan deskriptif, pernyataan fakta, definisi dan sebagainya. Contoh tuturan konstatif adalah 'lelaki itu pelaku pencurian di rumah saya' yang dituturkan seorang saksi di pengadilan mempunyai konsekuensi penilaian benar atau salah pada isi tuturannya.

Kategori yang kedua, yakni tuturan performatif. Menurut Austin, tuturan performatif adalah tuturan yang [...] do not 'describe' or 'report' or constate anything at all, are not 'true or false'; and [...] the uttering of the sentence is, or is part of, the doing of an action, which again would not normally be described as saying something (Austin, 1962). Berdasarkan definisi tersebut dapat dipahami tuturan performatif merupakan tuturan yang membentuk atau menciptakan tindakan. Tuturan performatif bukan tuturan yang bertujuan menjelaskan, menyatakan, ataupun semua tuturan yang bersifat deskripsi, yang mempunyai konsekuensi penilaian benar tidaknya tuturan atau proposisi yang dituturkan.

Kondisi-kondisi tertentu menurut Austin dapat menjadi syarat terpenuhinya tindak performatif apabila memenuhi kondisi felisitas, yakni kondisi happy 'bahagia'. Apabila syarat-syarat yang ada dalam tuturan terpenuhi, disebut happy 'senang'. Apabila syarat-syarat tidak terpenuhi disebut kondisi unhappy 'tidak senang' atau kondisi infelicities. Selanjutnya, Austin membagi kondisi infelicities menjadi dua jenis, yakni misfires, salah sasaran dan abuses salah penggunaan.

Kondisi salah sasaran dibagi menjadi dua kategori, yakni misinvocations salah penempatan dan 'misexecutions "salah eksekusi". Kondisi infelicities yang kedua, yakni abuses yang berkaitan dengan perasaan, ketulusan, dan tindakan penutur. Pada saat seorang penutur menuturkan ucapan selamat padahal dalam hati 
terdapat perasaan tidak senang dan nyaman merupakan salah satu contoh kondisi abuses infelicities.

Selanjutnya, Austin membagi tindak tutur menjadi tiga, yakni tindak lokusi, ilokusi, dan perlokusi yang terjadi pada saat tuturan disampaikan. Tindak menuturkan sesuatu disebut tindak lokusi. Austin menjelaskan bahwa tindakan lokusi sekadar menuturkan sesuatu, menyampaikan informasi, berbicara, menanyakan dan lain-lain (Austin, 1962, p. 108; Saifudin, 2020). Sebuah tuturan lokusi akan patuh pada kondisi kebenaran dan membutuhkan akal/rasa dan referensi agar dapat dipahami. Referensi sebuah tindakan lokusi tergantung pada pengetahuan pembicara pada saat penuturan (Austin, 1962, p. 143; Saifudin, 2020).

Selanjutnya, tindak yang kedua adalah tindak ilokusi. Tindak ilokusi merupakan tindak melakukan sesuatu berdasarkan hal yang dituturkan (Habermas, 1998; Saifudin, 2020). Ilokusi adalah apa yang dicapai dengan mengkomunikasikan niat untuk mencapai sesuatu. Tuturan dapat mengandung 'daya' tertentu. Melalui tuturan orang dapat menciptakan sesuatu yang baru, dapat membuat orang melakukan sesuatu, mengubah keadaan, dan lain-lain. Berikutnya, tindak perlokusi merupakan tindakan atau keadaan pikiran yang ditimbulkan oleh, atau sebagai konsekuensi dari, mengatakan sesuatu. Austin (Saifudin, 2020) mengungkapkan bahwa tindak perlokusi berupa apa yang penutur hasilkan atau capai dengan mengatakan sesuatu. Capaian itu dapat berupa meyakinkan, membujuk, menghalangi, mengatakan, mengejutkan atau menyesatkan seseorang. Dengan demikian, tindak perlokusi harus dipahami sebagai hubungan sebab akibat antara dua peristiwa. Penyebabnya adalah produksi tuturan oleh penutur dan akibatnya berupa tindakan petutur sesuai dengan isi tuturan.

Tindak perlokusi harus dibedakan dengan lokusi dan terlebih lagi harus dibedakan dengan ilokusi. Efek atau dampak dari tuturan (lokusi) yang dituturkan yang di dalamnya mengandung maksud tertentu (ilokusi) masuk kategori perlokusi. Sebuah tindak perlokusi lebih bersifat alami, tidak diatur oleh aturan dan tidak dapat dikonfirmasi dengan pertanyaan-pertanyaan.

\section{B. METODE}

Penelitian ini menggunakan metode penelitian kualitatif deskriptif (Moleong, 1994, p. 6). Sumber data penelitian ini pemaknaan kosakata kategori perang bahasa di Kamus Besar Bahasa Indonesia $V$, peraturan perundangan terkait, dan kasus-kasus hukum terkait kebahasaan. Teknik pengumpulan data dengan menggunakan studi dokumen, yakni $K B B I V$, peraturan perundangan terkait, dan kasus-kasus hukum kebahasaan. Sedangkan teknik analisa data menggunakan model interaktif, seperti yang dikemukakan Miles \& Huberman (2007, pp. 19-20) yang terdiri atas tiga komponen analisis, yaitu reduksi data, sajian data, dan penarikan simpulan atau verifikasi yang dilakukan dalam bentuk interaktif dengan proses pengumpulan data. Data-data kasus kebahasaan direduksi untuk menguatkan analisis definisi kosakata perang bahasa di $K B B I V$ dan peraturan perundangan terkait. Data definisi kosata perang bahasa $K B B I V$, peraturan perundangan terkait, dan kasus-kasus hukum kebahasaan disajikan dan dianalisis untuk ditarik simpulan definisi baru kosakata terkait perang bahasa.

\section{PEMBAHASAN}

Kasus hukum terkait data kebahasaan semakin marak. Pemaknaan yang 
multitafsir terkait kosakata dalam perang bahasa menimbulkan banyaknya kasus kebahasaan dan beragamnya penafsiran ahli bahasa. Berikut ini redefinisi kosakata terkait perang bahasa meliputi saran, kritik, ejekan, hasutan, pencemaran nama baik, hinaan, dan fitnah dalam konteks kasus hukum berdasarkan pemaknaan dalam Kamus Besar Bahasa Indonesia $V$, peraturan perundangan terkait, dan kasuskasus hukum terkait kebahasaan.

\section{Saran}

Perang bahasa yang memiliki derajat paling bawah adalah saran. Kata 'saran' ("KBBI Daring," 2020), dapat dimaknai dengan pendapat (usul, anjuran, cita-cita) yang dikemukakan untuk dipertimbangkan. Kata 'saran' secara semantis termasuk kata positif. Sebuah saran termasuk dalam tuturan performatif dengan membentuk atau menciptakan tindakan sesuai dengan yang diharapkan penutur. Tuturan yang berupa 'saran' dapat dikategorikan felisitas rasa senang dan kepedulian kepada petutur.

Seseorang ketika memberikan saran (lokusi) tuturan tersebut memiliki maksud seperti yang diinginkan penutur (ilokusi). Apabila tuturan tidak ditindaklanjuti, berarti tuturan tersebut hanya bernilai ilokusi karena mengandung makna dan tujuan tertentu. Seseorang melalui sebuah saran memungkinkan untuk dapat menciptakan dan mengkreasikan sesuatu yang baru. Selian itu, saran yang diterima dapat membuat orang melakukan sesuatu, mengubah keadaan dan lainlain menuju hal yang lebih baik (ilokusi). Selain itu, apabila saran yang diberikan ditindaklanjuti lawan tutur (petutur), tuturan tersebut dapat bernilai perlokusi. Sebuah saran yang sifatnya membangun/ konstruktif dan dikemas dengan menggunakan bahasa yang santun cenderung diterima dan tidak berpotensi jeratan hukum.

Dengan demikian, dapat diredefinisikan pengertian kata 'saran' adalah pendapat (usul, anjuran, cita-cita) bernilai rasa positif dan memiliki daya performatif yang dikemukakan untuk dipertimbangkan agar membentuk atau menciptakan tindakan sesuai dengan yang diharapkan penutur (pemberi saran), sebagai bentuk rasa senang kepada petutur (penerima saran).

\section{Kritik}

Perang bahasa level kedua adalah kritik. Pada era keterbukaan seperti sekarang ini, seseorang dengan begitu mudah menyampaikan kritikan. Kebebasan pendapat dan keberadaan media sosial memungkinkan seseorang menyampaikan kritikan kepada siapa saja, bahkan kepada seorang presiden. Berdasarkan pemaknaan yang terdapat dalam $K B B I V$ 'kritik' adalah kecaman atau tanggapan, kadang-kadang disertai uraian dan pertimbangan baik buruk terhadap suatu hasil karya, pendapat dan sebagainya ("KBBI Daring," 2020). Selanjutnya, secara etimologis kata kritik berasal dari bahasa Yunani clitikos yang artinya 'membedakan'. Kata kritik diturunkan dari bahasa Yunani kuno krités yang artinya orang yang menyampaikan pendapat/pandangan dengan disertai alasanalasan, pertimbangan nilai, interpretasi, atau pengamatan.

Sebuah 'kritik' termasuk tuturan performatif. Kritikan tidak sekadar tuturan yang bertujuan menjelaskan, menyatakan, ataupun bersifat deskripsi yang mempunyai konsekuensi penilaian benar tidaknya tuturan yang disampaikan. Sebagai tuturan performatif, kritikan membentuk atau menciptakan tindakan sesuai 
dengan yang disampaikan pengkritik. Tuturan 'kritik' hendaknya didasari rasa senang penutur yang dalam keadaan felisitas rasa senang.

Ketika seseorang menyampaikan sebuah kritikan, selayaknya menyampaikan dalam rangka memperbaiki pendapat, perilaku, atau sebuah kebijakan. Jangan sampai sebuah kritikan disampaikan atas dasar kebencian terhadap pribadi seseorang. Sebuah 'kritik' yang baik semestinya dilakukan dengan menggunakan pilihan kata yang tidak menyinggung perasaan, sopan, bijaksana, dan tidak mempermalukan seseorang tanpa mengurangi esensi kritikan yang disampaikan.

Sebuah 'kritik' dilakukan dengan menyampaikan tuturan (lokusi). Sebuah 'kritik' memiliki daya sesuai dengan apa yang dikritik (ilokusi). Kritikan sering kali menggunakan diksi yang pedas. Sebuah kritikan tentunya memiliki maksud untuk mengoreksi kelemahan atau kekurangan dengan berharap ada perhatian dan perbaikan. Sebuah kritikan yang diterima akan dapat memiliki efek atau dampak (perlokusi) berupa perbaikan sesuai yang disampaikan. Kritikan juga bisa disampaikan tanpa ada tindak lanjut dari pihak yang dikritik. Sebuah kritikan disampaikan masih dalam kerangka murni ingin memberikan masukan perbaikan. Pilihan bahasa selayaknya masih dalam batas kesantunan berbahasa. Menurut Manthovani (2019) sebuah kritikan bukanlah suatu tindak pidana, namun sebuah kritikan yang disampaikan dengan perasaan kebencian untuk memfitnah, mencemarkan nama baik, dan menghina tentunya dapat dipidana.

Berdasarkan analisis tersebut dapat diredefinisi pengertian 'kritik' adalah sebuah kecaman, tanggapan, yang terkadang disertai uraian pertimbangan mengenai baik buruk yang memiliki daya performatif membentuk atau menciptakan tindakan terhadap suatu hasil karya, pendapat dan sebagainya sejatinya dalam rangka perbaikan/konstruktif sering kali menggunakan diksi yang pedas dengan maksud mengoreksi kelemahan atau kekurangan untuk dapat perhatian dan perbaikan, apabila diterima dapat memiliki dampak perbaikan dan atau tanpa ada tindak lanjut dari pihak yang dikritik dalam kerangka murni ingin memberikan masukan perbaikan yang hendaknya disampaikan atas dasar rasa senang penutur dalam keadaan felisitas rasa senang yang selayaknya masih dalam batas kesantunan berbahasa.

\section{Ejekan}

Perang bahasa pada tahap ketiga adalah 'ejekan'. Dalam KBBI V ("KBBI Daring," 2020) 'ejekan' dimaknai dengan perbuatan mengejek, olok-olok, sindiran. 'Ejekan' secara umum masuk dalam tuturan konstatif termasuk semua ucapan deskriptif, pernyataan fakta, definisi dan sebagainya; yaitu tuturan yang melaporkan, menginformasikan, dan menyatakan. Sebuah 'ejekan' sebagai sebuah tuturan (lokusi) memiliki maksud (lokusi) untuk menyerang pribadi pihak yang dijelekkan. Hal itu mengakibatkan ketersinggungan atau bisa juga menimbulkan reaksi dari pihak yang diejek. 'Ejekan' yang berlebihan dan menyerang pribadi seseorang apalagi di media publik/media sosial berpotensi mengarah penghinaan dan pencemaran nama baik.

Dengan demikian, dapat diredefinisi bahwa makna 'ejekan' adalah perbuatan mengejek, mengolok-olok, menyindir yang masuk dalam tuturan konstatif yakni tuturan berupa ucapan deskriptif, pernyataan fakta, definisi dan sebagainya yang berisi laporan, informasi, dan pernyataan menyerang pribadi pihak yang dijelekkan sehingga mengakibatkan ketersinggungan atau reaksi dari pihak yang diejek 
apabila berlebihan dan disampaikan di media publik/media sosial berpotensi mengarah penghinaan dan pencemaran nama baik.

\section{Hasutan}

Perang bahasa level empat adalah 'hasutan'. 'Hasutan' dalam KBBI V ('KBBI Daring," 2020) dimaknai dengan perbuatan, perkataan dan sebagainya yang bersifat menghasut. 'Menghasut' adalah membangkitkan hati orang supaya marah (melawan, memberontak, dan sebagainya) atau menggalakkan (anjing) ("KBBI Daring," 2020). Mengajak secara negatif untuk melawan, marah, memberontak, dan sebagainya (sejenis dengan memberontak). Sebuah hasutan, dapat dikatakan sebagai tuturan performatif karena dengan hasutan tersebut dapat menimbulkan tindakan seperti yang dihasutkan. Sebuah hasutan berupa tuturan (lokusi) tentunya memiliki maksud (perlokusi) sesuai dengan yang dihasutkan. Dalam banyak kasus, hasutan dapat menimbulkan tindakan yang sesuai yang disangkakan.

Contoh kasus terkait hasutan seperti yang disampaikan artis Ahmad Dhani yang diduga menyebarkan hasutan kebencian terhadap kelompok tertentu melalui akun Twitter. Dhani mengunggah kicauan dengan menggunakan akun @ahmaddhaniprast. Dalam kicauan tersebut diduga ditujukan untuk menghasut dengan penuh kebencian terhadap para pendukung Ahok. Tuturan tersebut berupa "PARA PEMBELA PENISTA AGAMA ADALAH BAJINGAN YANG PERLU DI LUDAHI MUKA NYA".

Secara singkat menilik tuturan Ahmad Dani tersebut, termasuk tuturan performatif. Sebuah hinaan timbul karena rasa tidak senang (infelicities) abuses. Sesuai dengan pernyataan Ahmad Dani tersebut, publik dihasut untuk meludahi para pembela penista agama (Ahok). Pernyataan tersebut memiliki maksud (lokusi) bahwa orang-orang yang membela Ahok seperti bajingan yang layak diludahi mukanya. Selain itu, tuturan tersebut dapat berefek atau berdampak (perlokusi) untuk melakukan persekusi (meludahi) orang-orang yang dianggap mendukung Ahok. Dalam kasus tersebut, Ahmad Dani divonis bersalah.

Berdasarkan uraian dan analisis kasus tersebut dapat diredefinisikan 'hasutan' adalah perbuatan, perkataan dan sebagainya yang bersifat menghasut membangkitkan hati orang supaya marah (melawan, memberontak, dan sebagainya) atau menggalakkan (anjing) mengajak secara negatif untuk melawan, marah, memberontak, dan sebagainya (sejenis dengan memberontak) dapat dikatakan sebagai tuturan performatif karena dengan hasutan tersebut dapat menimbulkan tindakan seperti yang dihasutkan, sebuah hasutan berupa tuturan tentunya memiliki maksud dan dapat menimbulkan tindakan sesuai yang disangkakan.

\section{Pencemaran Nama Baik}

Pencemaran nama baik merupakan level kelima dalam perang bahasa. Berdasarkan $K B B I V$, pencemaran berarti proses, cara, perbuatan mencemari atau mencemarkan; pengotoran (Badan Pengembangan dan Pembinaan Bahasa, 2020). Dengan demikian, pencemaran nama baik dapat dimaknai proses, cara, perbuatan mencemari atau mencemarkan; pengotoran nama baik seseorang.

Berdasarkan peraturan perundangan terkait, pencemaran nama baik dalam arti umum adalah proses, cara, perbuatan yang menyebabkan nama baik orang lain menjadi buruk atau tercela. Adapun kata pencemaran sebagai istilah yang dimaksud dalam pasal 310 KUHP dan juga pasal 27 ayat (3) Undang-Undang RI 
Nomor 19 Tahun 2016 tentang perubahan atas Undang-Undang RI Nomor 11 Tahun 2008 tentang Informasi dan Transaksi Elektronik mengandung tiga unsur makna, yaitu: (1) perbuatan sengaja menyerang kehormatan atau nama baik seseorang, (2) dengan cara menuduhkan sesuatu hal, dan (3) dengan maksud jelasjelas supaya hal itu diketahui umum (Menteri Hukum dan Hak Azasi Manusia Republik Indonesia, 2018). Berdasarkan pengertian pencemaran nama baik dalam pasal tersebut dapat dipahami sebagai perbuatan sengaja menyerang kehormatan atau nama baik seseorang dengan cara menuduhkan sesuatu hal, dan dengan maksud jelas-jelas supaya hal itu diketahui umum.

Salah satu contoh kasus pencemaran nama baik adalah kasus pencemaran nama baik Dosen Universitas Syah Kuala (Unsyiah), Syaiful Mahdi, divonis tiga tahun penjara, karena terbukti bersalah melakukan tindak pidana pencemaran nama baik di media sosial. Tuturan tersebut berupa, "Innalilahi wa innailaihi rajiun. Dapat kabar duka matinya akal sehat dalam jajaran pimpinan Fakultas Teknik Unsyiah saat tes PNS kemarin. Bukti determinisme teknik itu sangat mudah dikorup" (Agus, 2020). Menilik kasus tersebut, tuturan tersebut termasuk tuturan konstatif. Penutur memberikan pernyataan dan menginformasikan tentang telah matinya akal sehat dalam jajaran pimpinan Fakultas Teknik Unsyiah sat tes PNS yang membuktikan adanya determinasi yang memungkinkan teknik itu sangat mudah dikorup. Tuturan (lokusi) tersebut memiliki maksud (ilokusi) menuduh jajaran pimpinan Fakultas Teknik Unsyiah melakukan korupsi (diduga suap) dalam pelaksanaan tes PNS. Penutur juga bermaksud menyiarkan bahwa akal sehat jajaran pimpinan Fakultas Teknis Unsyiah telah mati. Tentunya, pernyataan tersebut karena disampaikan di media sosial, dapat berdampak pada pencemaran nama baik jajaran pimpinan Fakultas Teknik Unsyiah.

Sebagai perbandingan, terdapat kasus lain dengan dakwaan pencemaran nama baik yang akhirnya bebas. Kasus dugaan pencemaran nama baik seorang istri salah satu perwira polisi, Febi Nur Amelia. Ibu Rumah Tangga (IRT) berusia 29 tahun tersebut dinyatakan tidak bersalah dalam perkara dugaan pelanggaran UU ITE. Wanita dalam kasus tersebut diputus tidak bersalah oleh majelis hakim yang diketuai Sri Wahyuni di Pengadilan Negeri (PN) Medan, Selasa, 6 Oktober 2020. Febi diputus tidak terbukti mencemarkan nama baik saat menagih utang kepada Fitriani Manurung, istri seorang perwira berpangkat Komisaris Besar (Kombes) Polisi, melalui media sosial Instagram.

Majelis hakim dalam memberikan pertimbangan terkait putusan tersebut, menyatakan bahwa Fitriani terbukti meminjam uang Rp 70 juta kepada Febi. Meskipun Fitriani membantah fakta tersebut, fakta persidangan menunjukkan bahwa ada dua bukti transfer kepada rekening suami Fitriani. Berdasarkan pandangan majelis hakim, Febi dalam kapasitas membela haknya agar uang yang dipinjam itu dapat dibayarkan oleh istri polisi tersebut. Sedangkan fakta berupa Fitriani yang merasa malu dan terserang nama baiknya, hal itu bukanlah karena perbuatan Febi. Dampak itu sebagai akibat perbuatan saksi sendiri yang melakukan suatu perbuatan tidak patut karena tidak membayar utang dan merasa tidak punya utang. (Efendi, 2020).

Kasus tersebut menarik untuk dicermati. Kasus tersebut dipicu unggahan Febi di Instastory akunnya. 


\begin{abstract}
"SEKETIKA TERINGAT SAMA IBU KOMBES YG BELUM BAYAR HUTANG 70 JUTA TOLONG BGT DONK IBU DIBAYAR HUTANGNYA $\quad Y G \quad$ SUDAH BERTAHUN-TAHUN @FITRI_BAKHTIAR. AKU SIH Y ORANGNYA GK RIBET KLO LAH MMNG PUNYA HUTANG INI ORANG SUSAH BGT PASTINYA AKU IKHLASKAN TAPI BERHUBUNG BELIAU INI KAYA RAYA JADI HARUS DIMINTA DONK BERDOSA JUGA KLO HUTANG GK DIBAYAR KAN@FITRI_BAKHTIAR. Nah ini Yg punya Hutang 70 Juta Ini foto diambil sewaktu Di Bandara Jakarta, Horor klo ingat yg beginian Mati nanti bakal ditanya lho soal hutang piutang (CNN Indonesia, 2020).
\end{abstract}

Unggahan Febi tersebut termasuk tuturan performatif, dengan diharapkan memberikan dampak agar FM segera dibayar hutang. Hal itu ditimbulkan rasa tidak senang (infelicities) abuses yang berkaitan dengan perasaan Febi yang sudah mencoba menagih dengan berbagai cara, ketulusan demi menagih utang, dan tindakan penutur yang ingin agar uangnya segera dikembalikan. Tuturan tersebut memiliki maksud (ilokusi) menagih utang. Berdasarkan keterangan yang disampaikan Febi, berbagai upaya menagih sudah dilakukan dan sulit untuk dihubungi. Sebagai alternatif, Febi mengunggah pernyataan itu. Pernyataan tersebut tentu memiliki efek (perlokusi) berupa tercorengnya muka karena aibnya (memiliki utang) diketahui publik. Efek itu tentu, meski tidak diakui Febi, diharapkan menimbulkan efek lanjutan FM untuk segera membayar utang. Terlebih lagi, Fitri mampu menunjukkan bukti bahwa FM benar berutang kepada Fitri.

Menilik dua kasus tersebut, dapat dipahami bahwa tercemarnya nama baik seseorang tidak selalu bersalah di mata hukum. Apabila hal yang disampaikan tersebut merupakan sebuah kebenaran dan tidak ada niat mencemarkan nama baik, meskipun efeknya tetap tercemarnya nama baik seseorang, yang bersangkutan dapat bebas dari jeratan hukum. Oleh karena itu, berdasarkan berbagai definisi dan konteks kasus di atas, dapat disimpulkan redefinisi pencemaran nama baik adalah proses, cara, perbuatan yang menyebabkan nama baik orang lain menjadi buruk atau tercela yang sengaja menyerang kehormatan atau nama baik seseorang dengan cara menuduhkan sesuatu hal, dan dengan maksud jelas-jelas supaya hal itu diketahui umum. Tercemarnya nama baik seseorang tidak selalu bersalah di mata hukum apabila hal yang disampaikan tersebut merupakan sebuah kebenaran dan tidak ada niat mencemarkan nama baik, meskipun efeknya tetap tercemarnya nama baik seseorang, yang bersangkutan dapat bebas dari jeratan hukum.

\title{
6. Hinaan
}

Perang bahasa yang banyak menimbulkan laporan hukum adalah 'penghinaan'. 'Penghinaan' mengandung pengertian proses, cara, perbuatan menghina(kan); menistakan ("KBBI Daring," 2020). Selanjutnya, menghina ("KBBI Daring," 2020) berarti merendahkan; memandang rendah (hina, tidak penting). Selain itu, juga dapat dimaknai memburukkan nama baik orang; menyinggung perasaan orang (seperti memaki, menistakan). Kata-kata yang bermuatan penghinaan berarti unsur bahasa (berupa kata, frasa, klausa, atau kalimat) yang merendahkan, memandang rendah (hina, tidak penting); memburukkan nama baik orang. 
Kasus terkait penghinaan begitu banyak di Indonesia. Kasus penghinaan yang ditujukan kepada Jonru Ginting yang diduga menyebarkan ujaran kebencian melalui konten yang diunggah di media sosial. Salah satu unggahan Jonru yang termasuk ujaran kebencian terhadap Quraish Shihab. Sesuai unggahan tersebut, Jonru menyebut Quraish Shihab tidak pantas menjadi imam karena pernyataannya yang menyebut wanita Muslim tidak perlu menggunakan jilbab.

Jonru mengajak umat Islam untuk tidak salat Idul Fitri di Masjid Istiqlal jika imamnya adalah Quraish Shihab. Perbuatan Jonru tersebut didakwa dengan Pasal 28 Ayat (2) juncto Pasal 45A Ayat (2) dan atau Pasal 35 juncto Pasal 51 UU RI Nomor 19 Tahun 2016 Tentang Perubahan atas UU RI Nomor 11 Tahun 2008 Tentang ITE dan atau Pasal 4 huruf (b) angka (1) juncto Pasal 16 UU RI Nomor 40 Tahun 2008 Tentang Penghapusan Diskriminasi Ras dan Etnis dan atau Pasal 156 KUHP Tentang Penghinaan Terhadap Suatu Golongan (Tim Genbest.id, 2017).

Apabila dicermati, pernyataan Jonru tersebut termasuk tuturan performatif yang memiliki dampak mengajak umat Islam untuk tidak salat Idul Fitri di Masjid Istiqlal jika imam salatnya Quraish Shihab. Pernyataan tersebut timbul karena perasaan tidak senang (infelicities) abuses terlebih lagi perasaan dan tindakan penutur yang tulus. Tuturan (lokusi) Jonru tersebut memiliki maksud menghina Quraish Shihab karena dalam pandangan Jonru menghina seorang Quraish Shihab tidak pantas menjadi seorang imam salat Idul Fitri di Masjid Istiqlal disebabkan pernyataan-pernyataan Quraish Shihab yang menyebutkan bahwa seorang wanita Muslim tidak perlu memakai jilbab. Tentunya, tuturan tersebut berefek (perlokusi) keresahan di kalangan umat Islam karena menghasut umat Islam tidak salat Idul Fitri di Masjid Istiqlal apabila Quraish Shihab yang menjadi imam salatnya.

Berdasarkan definisi dan analisis tersebut dapat disimpulkan bahwa pengertian penghinaan dalam konteks luas dapat diartikan sebagai proses, cara, perbuatan menghina(kan); menistakan merendahkan; memandang rendah (hina, tidak penting) dengan menggunakan unsur bahasa (berupa kata, frasa, klausa, atau kalimat) yang merendahkan, memandang rendah (hina, tidak penting); memburukkan nama baik orang yang ditimbulkan rasa tidak senang (infelicities) abuses yang dapat dikatakan sebagai tuturan performatif yang dapat menimbulkan tindakan memburukkan nama baik orang; menyinggung perasaan orang (seperti memaki, menistakan).

\section{Fitnah}

Perang bahasa tingkat tertinggi adalah fitnah. Pengertian fitnah ("KBBI Daring," 2020) adalah perkataan bohong atau tanpa berdasarkan kebenaran yang disebarkan dengan maksud menjelekkan orang (seperti menodai nama baik, merugikan kehormatan orang). Fitnah juga dapat dimaknai perbuatan yang menimbulkan kekacauan, seperti mengusir orang lain dari kampung halamannya, merampas harta, menyakiti orang lain, menghalangi dari jalan Allah, atau melakukan kemusyrikan. Komponen makna fitnah perkataan tidak sesuai kenyataan, perkataan disebarkan, dan ada unsur menjelekkan.

Sebagai contoh kasus hukum terkait fitnah, salah satunya kasus yang menjerat HP (23), admin akun Instagram Muslim_Cyber1. HP mengunggah tangkapan percakapan palsu antara Kapolri Jenderal Pol Tito Karnavian dengan Kabid Humas Polda Metro Jaya Kombes Argo Yuwono. Dalam tangkapan percakapan tersebut seolah berisi percakapan Kapolri Jenderal Pol Tito 
Karnavian dengan Kabid Humas Polda Metro Jaya Kombes Argo Yuwono yang membahas kasus pemimpin Front Pembela Islam (FPI) Habib Rizieq Shihab. Dalam potongan pesan tersebut terdapat bagian yang seolah-olah Tito dan Argo berencana untuk merekayasa kasus dengan tujuan menjatuhkan Habib Rizieq Shihab. Selain membuat hoaks percakapan antara Tito dan Argo, HP dalam akun @ muslim_cyber1 juga membuat unggahan berbau SARA, fitnah, serta ujaran kebencian (Haryadi, 2017).

Berbeda dengan ujaran kebencian, fitnah dan penghinaan dilakukan dengan pernyataan-pernyataan yang menyinggung perasaan bahkan tidak sopan dan tidak ada niat untuk memperbaiki pendapat atau perilaku seseorang. Menilik kasus tersebut dapat dipahami bahwa dugaan fitnah terkait rekayasa percakapan antara Tito Karnavian dengan Argo Yuwono. Isi fitnah tersebut berisi percakapan keduanya yang seolah membahas kasus pemimpin Front Pembela Islam (FPI) Habib Rizieq Shihab. Rekayasa percakapan tersebut termasuk tuturan konstatif maupun performatif yang didasari rasa tidak senang (infelicities) abuses.

Tuturan rekayasa percakapan (ilokusi) tersebut memiliki maksud membuat persepsi publik seolah-seolah adanya rekayasa kasus yang dilakukan Tito dan Argo dengan tujuan untuk menjatuhkan Rizieq. Tentunya, rekayasa percakapan tersebut dapat berefek timbulnya kebencian terhadap Polri, terutama Tito Karnavian dan Argo Yuwono. Kondisi ini menimbulkan rasa tidak senang (infelicities) abuses.

Berdasarkan definisi dan analisis kasus tersebut dapat disimpulkan makna fitnah dalam konteks luas adalah perkataan tidak sesuai kenyataan, perkataan disebarkan, dan ada unsur menjelekkan perkataan bohong atau tanpa berdasarkan kebenaran yang disebarkan dengan maksud menjelekkan orang (seperti menodai nama baik, merugikan kehormatan orang) yang memiliki dampak performatif yang menimbulkan kekacauan, seperti mengusir orang lain dari kampung halamannya, merampas harta, menyakiti orang lain, menghalangi dari jalan Allah, atau melakukan kemusyrikan.

\section{PENUTUP}

Perang bahasa dapat meliputi saran, kritikan, ejekan, hasutan, pencemaran nama baik, penghinaan, dan fitnahan. Berdasarkan analisis terhadap definisi perang bahasa, berikut ini simpulan atas redefinisi kosakata perang bahasa. Redefinisi kata 'saran' adalah pendapat (usul, anjuran, cita-cita) bernilai rasa positif, tuturan memiliki daya performatif yang dikemukakan untuk dipertimbangkan untuk membentuk atau menciptakan tindakan sesuai dengan yang diharapkan penutur, sebagai bentuk rasa senang kepada petutur. Redefinisi kata 'kritik; adalah sebuah kecaman, tanggapan, yang terkadang disertai uraian pertimbangan mengenai baik buruk yang memiliki daya performatif membentuk atau menciptakan tindakan terhadap suatu hasil karya, pendapat, dan sebagainya sejatinya dalam rangka perbaikan/ konstruktif sering kali menggunakan diksi yang pedas dengan maksud mengoreksi kelemahan atau kekurangan untuk dapat perhatian dan perbaikan, apabila diterima dapat memiliki dampak perbaikan dan atau tanpa ada tindak lanjut dari pihak yang dikritik dalam kerangka murni ingin memberikan masukan perbaikan yang hendaknya disampaikan atas dasar rasa senang penutur dalam keadaan felisitas rasa senang yang selayaknya masih dalam batas kesantunan berbahasa. 
Redefinisi kata 'ejekan' adalah perbuatan mengejek, mengolok-olok, menyindir yang masuk dalam tuturan konstatif yakni tuturan berupa ucapan deskriptif, pernyataan fakta, definisi dan sebagainya yang berisi laporan, informasi, dan pernyataan menyerang pribadi pihak yang dijelekkan sehingga mengakibatkan ketersinggungan atau bisa juga menimbulkan reaksi dari pihak yang diejek apabila berlebihan dan disampaikan di media publik/media sosial berpotensi mengarah penghinaan dan pencemaran nama baik.

Redefinisi kata 'hasutan' adalah perbuatan, perkataan, dan sebagainya yang bersifat menghasut membangkitkan hati orang supaya marah (melawan, memberontak, dan sebagainya) atau menggalakkan (anjing) mengajak secara negatif untuk melawan, marah, memberontak, dan sebagainya (sejenis dengan memberontak) dapat dikatakan sebagai tuturan performatif karena dengan hasutan tersebut dapat menimbulkan tindakan seperti yang dihasutkan, sebuah hasutan berupa tuturan tentunya memiliki maksud dan dapat menimbulkan tindakan yang sesuai yang disangkakan.

Redefinisi 'pencemaran nama baik' adalah proses, cara, perbuatan yang menyebabkan nama baik orang lain menjadi buruk atau tercela yang sengaja menyerang kehormatan atau nama baik seseorang dengan cara menuduhkan sesuatu hal, dan dengan maksud jelas-jelas supaya hal itu diketahui umum. Tercemarnya nama baik seseorang tidak selalu bersalah di mata hukum apabila hal yang disampaikan tersebut merupakan sebuah kebenaran dan tidak ada niat mencemarkan nama baik, meskipun efeknya tetap tercemarnya nama baik seseorang, yang bersangkutan dapat bebas dari jeratan hukum.

Redefinisi 'penghinaan' adalah sebagai proses, cara, perbuatan menghina(kan); menistakan merendahkan; memandang rendah (hina, tidak penting) dengan menggunakan unsur bahasa (berupa kata, frasa, klausa, atau kalimat) yang merendahkan, memandang rendah (hina, tidak penting); memburukkan nama baik orang yang ditimbulkan rasa tidak senang (infelicities) abuses yang dapat dikatakan sebagai tuturan performatif yang dapat menimbulkan tindakan memburukkan nama baik orang; menyinggung perasaan orang (seperti memaki, menistakan).

Redefinisi 'fitnah' adalah perkataan tidak sesuai kenyataan, perkataan disebarkan, dan ada unsur menjelekkan perkataan bohong atau tanpa berdasarkan kebenaran yang disebarkan dengan maksud menjelekkan orang (seperti menodai nama baik, merugikan kehormatan orang) yang memiliki dampak performatif yang menimbulkan kekacauan, seperti mengusir orang lain dari kampung halamannya, merampas harta, menyakiti orang lain, menghalangi dari jalan Allah, atau melakukan kemusyrikan.

\section{DAFTAR PUSTAKA}

Agus, M. H. S. (2020). "Dosen Unsyiah divonis tiga bulan penjara karena pencemaran nama baik." Diakses dari https://www.antaranews.com/berita/1435168/dosen-unsyiah-divonis-tigabulan-penjara-karena-pencemaran-nama-baik pada tanggal 19 November 2020

Aziz, E. A. (2020). Model Resolusi Konflik Kebahasaan: Sebauh Refleksi Pengalaman. Jakarta.

Badan Pengembangan dan Pembinaan Bahasa. (2020). KBBI Daring. Diakses dari 
https://kbbi.kemdikbud.go.id/entri/nasionalisme pada tanggal 15 November 2020

CNN Indonesia. (2020). "Tagih Utang Istri Polisi via Medsos, Warga Medan Terancam Bui." Diakses dari https://www.cnnindonesia.com/nasional/20200715131900-12-

524950/tagih-utang-istri-polisi-via-medsos-warga-medan-terancam-bui pada tanggal 13 November 2020

Definisi. (2021). Diakses dari https://kbbi.kemdikbud.go.id/entri/definisi pada tanggal 23 Maret 2021

Efendi, R. (2020). "Tok, Terdakwa Pencemar Nama Baik Istri Kombes Polisi Divonis Bebas." Diakses dari https://www.liputan6.com/regional/read/4376137/tok-terdakwa-pencemarnama-baik-istri-kombes-polisi-divonis-bebas pada tanggal 19 November 2020

Gerintya, S. (2020). "Jerat UU ITE Banyak Dipakai oleh Pejabat Negara." Diakses dari https://tirto.id/jerat-uu-ite-banyak-dipakai-oleh-pejabat-negara-c7sk pada tanggal 17 Oktober 2020

Haryadi, M. (2017). "Ditangkap! Admin Akun Instagram yang Sebar Chat Palsu Kapolri-Kabid Humas Polda Metro Jaya." Diakses dari https://m.tribunnews.com/nasional/2017/05/29/ditangkap-admin-akuninstagram-yang-sebar-chat-palsu-kapolri-kabid-humas-polda-metrojaya?page $=$ all pada tanggal 18 November 2020

KBBI Daring. (2020). Diakses dari https://kbbi.kemdikbud.go.id/entri/propaganda pada tanggal 17 November 2020

Manthovani, R. (2019). "Meluruskan Istilah Kritik, Fitnah dan Ujaran Kebencian." Diakses https://www.hukumonline.com/berita/baca/lt5cf0a71edb75c/meluruskanistilah-kritik--fitnah-dan-ujaran-kebencian-oleh--reda-manthovani/ pada tanggal 19 November 2020

Menteri Hukum dan Hak Azasi Manusia Republik Indonesia. (2018). Undangundang Republik Indonesia Nomor 11 Tahun 2008 Tentang Informasi dan Transaksi Elektronik.

Miles, M. B., \& Huberman, A. M. (1992). Analisis Data Kualitatif. Jakarta: Penerbit Universitas Indonesia.

Moleong, L. J. (1994). Metodologi Penelitian Kualitatif (25th ed.). Bandung: PT Remaja Rosdakarya.

Prabowo, L. S. (2021). Transformasi Menuju POLRI Yang PRESISI yang Pada Uji Kelayakan dan Kepatutan Calon Kapolri di Hadapan Komisi III DPR RI Tahun 2021. Jakarta.

Saifudin, A. (2020). Teori Tindak Tutur dalam Studi Linguistik. LITE, Volume 15, 1-16. Diakses dari http://publikasi.dinus.ac.id/index.php/lite/article/download/3520/1884 pada tanggal 15 November 2020

Tim Genbest.id. (2017). "Ini Satu Postingan Jonru yang Dipermasalahkan Polisi." Diakses dari https://genbest.kompas.com/read/2017/10/06/17454101/inisatu-postingan-jonru-yang-dipermasalahkan-polisi pada tanggal 19 November 2020 